\title{
Model parameter transfer for streamflow and sediment loss prediction with SWAT in a tropical watershed
}

\author{
Vincent Roth - Tibebu Kassawar \\ Nigussie - Tatenda Lemann
}

Received: date / Accepted: date

\begin{abstract}
Distributed hydrologic models are increasingly used to describe the spatiotemporal dynamics of water and sediment fluxes within basins. In data-scarce regions like Ethiopia, oftentimes, discharge or sediment load data are not readily available and therefore researchers have to rely on input data from global models with lower resolution and accuracy. In this study we evaluated a model parameter transfer from a 100 hectare (ha) large subwatershed (Minchet) to a 4800 ha catchment in the highlands of Ethiopia using the Soil and Water Assessment Tool (SWAT). The Minchet catchment has long-lasting time series on discharge and sediment load dating back to 1984, which were used to calibrate the subcatchment before (a) validating the Minchet subcatchment and (b) through parameter transfer validating the entire Gerda watershed without prior calibration. Uncertainty analysis was carried out with the Sequential Uncertainty Fitting-2 (SUFI-2) with SWATCup and ArcSWAT2012. We used a similarity approach, where the complete set of model parameters is transposed from a donor catchment that is very similar regarding physiographic attributes (in terms of landuse, soils, geology and rainfall patterns). For calibration and validation the Nash-Sutcliff model efficiency, the Root Mean Square Error-observations Standard Deviation Ratio (RSR) and the Percent Bias (PBIAS) indicator for model performance ratings during calibration and validation periods were applied. Goodness of fit and the degree to which the calibrated model accounted for the uncertainties were assessed with the P-factor and the R-factor of the SUFI-2 algorithm. Results

\author{
Vincent Roth \\ Centre for Development and Environment (CDE), Hallerstrasse 10, 3012 Bern, Switzerland \\ Tel.: +41316318822 \\ E-mail: vincent.roth@cde.unibe.ch \\ Tibebu Kassawmar \\ Water and Land Resource Center, P.O. Box 3880, Addis Ababa, Ethiopia \\ Tatenda Lemann \\ Centre for Development and Environment (CDE), Hallerstrasse 10, 3012 Bern, Switzerland
}


show that calibration and validation for streamflow performed very good for the subcatchment as well as for the entire catchment using model parameter transfer. For sediment loads, calibration performed better than validation and parameter transfer yielded satisfactory results, which suggests that the SWAT model can be used to adequately simulate monthly streamflow and sediment load in the Gerda catchment through model parameter transfer only.

Keywords Streamflow · Sediment load · SWAT · SUFI-2 · Uncertainty analysis $\cdot$ model parameter transfer $\cdot$ Ethiopia

\section{Introduction}

Key aspects of regional hydrological assessments are accurate and reliable predictions of water fluxes and state variables such as runoff, evapotranspiration, groundwater recharge and sediment loads in watersheds. Distributed hydrological models are increasingly being used for this purpose, relying to a greater extent on computing power and remotely sensed information (Kumar et al, 2013). The spatial distribution of hydrological variables simulated with those models is achieved by accounting for spatial variability of typical physical characteristics like topography, land use/land cover, soil types and meteorological variables such as temperature and precipitation. Recurrent challenges in modelling medium to large scale watersheds (102 to $105 \mathrm{~km}^{2}$ ) are typically overparameterization, parameter non-identifiability, non-transferability of parameters across calibration scales and across spatial scales and locations and last but not least, increasing computing time (Beven, 1993; Haddeland, 2002; Samaniego et al, 2010; Kumar et al, 2013). Because distributed hydrological models are spatially complex and deal with large numbers of unknown parameters, parameterization techniques have to be applied. The most common technique is based on the hydrological response unit (HRU), in which complexity is reduced through cell grouping of homogeneous units, using basin physical characteristics (Beven, 1993; Abbaspour et al, 2007b; Arnold et al, 2012; Kumar et al, 2013). Other major challenges when applying distributed hydrological models are the non-transferability of model parameters through spatial resolution and transferability of parameters across scale and space. Several studies have shown that shifting model parameters across calibration scale generates bias in simulation of water fluxes and state variables (Haddeland, 2002; Liang et al, 2004; Samaniego et al, 2010). Similarly, discrepancies occur when parameters are transferred across locations (Merz and Blöschl, 2004; Samaniego et al, 2010; Smith et al, 2012; Singh et al, 2012). However, relatively few researchers have attempted to model parameter transfer so far and none, to our knowledge, have ever tried it in Ethiopia.

There have been numerous studies conducted in the Ethiopian highlands on modelling discharge and soil erosion with SWAT (Ndomba et al, 2008; Mekonnen et al, 2009; Setegn et al, 2010; Easton et al, 2010; Betrie et al, 2011; Notter et al, 2012; Yesuf et al, 2016; Lemann et al, 2016) to cite an incomplete list only. All of them focused on modeleling with limited measured data and none 
did attempt the model parameter transfer for lack of appropriate opportunities. The setup in this study is probably quite unique and non-existent in Ethiopia.

Several studies, outside of Ethiopia, focussed on temporal transfers of model parameters(Bingner et al, 1997; Van Liew and Garbrecht, 2003; Abbaspour et al, 2007b; Chaubey et al, 2010; Sheshukov et al, 2011; DouglasMankin et al, 2013; Seo et al, 2014) and others more on a spatial transfer (Vandewiele and Elias, 1995; Santhi et al, 2001; Merz and Blöschl, 2004; Parajuli et al, 2009; He et al, 2011; Kumar et al, 2013).

For example Merz and Blöschl (2004) examined the performance of various methods of regionalizing parameters of a conceptual catchment model in 308 Austrian catchments. They concluded that the methods based on spatial proximity performed better than those based on physiographic catchment attributes. Similarly Kumar et al (2013) concluded that the similarity approach, where a complete set of parameters is transposed from a donor catchment that is most similar in physiographic terms performed best. Kokkonen et al (2003) transferred the complete parameter set from the catchment outlet, while McIntyre (2004) defined the most similar catchment in terms of area, precipitation and baseflow and Parajka et al (2005) used the mean for elevation, stream network density, and lake index to define similarity.

The aim of the present study is to analyse the effects of this parameter transfer technique on the simulation of water fluxes and sediment loads at multiple modelling scales and locations. We specifically investigate the model parameter transfer from one subcatchment to the entire watershed for sediment load and streamflow modelling.

\section{Methodology}

\subsection{Study area}

The Gerda watershed is located in the central Ethiopian Highlands of the Amhara Regional State (See Figure 1 and table 3 for details). It is situated approximately $45 \mathrm{~km}$ northwest of Debre Markos and $230 \mathrm{~km}$ northwest of Addis Abeba and covers a drainage area of about 4860.4 ha. The watershed is characterized by gently sloping to undulating hills at the top of the catchment, a rugged and dissected topography with steep slopes in the middle, and a gently sloping bottom part. Elevations range from 1980 to $2600 \mathrm{~m}$ a.s.l. The Minchet river, referred to as the Gerda river downstream, flows in a southwesterly direction to the outflow at Yechereka. Climate is dominated by a unimodal rainfall regime with a long rainy season from June to September (Kremt) and a long dry season from October to May. The average annual precipitation is $1690 \mathrm{~mm}$ and the mean annual temperature is $16^{\circ} \mathrm{C}$. Local land use is dominated by smallholder rain-fed farming systems, emphasizing grain production, ox-ploughing, and uncontrolled grazing practices (SCRP, 2000). The Gerda watershed has undergone no significant development process 
since the early 1980s and no mechanization or major hydrological change have occurred.

\subsection{SWAT model configuration}

The Soil and Water Assessment Tool (SWAT2012 rev. 620) was used to assess streamflow and sediment load prediction uncertainty through the ArcSWAT interface (Version 2012.10_1.14). SWAT is a physically based river basinor watershed-modelling tool, which is capable of continuous simulation over long time periods.

The SWAT model divides the watershed into subbasins for better representation of the spatial heterogeneity. The subbasins are further discretized into hydrologic response units (HRUs), which are a unique combination of soil types, landuse types and slope. For every single HRU the soil water content, surface runoff, crop growth including management practice and sediment yield is compiled and then aggregated to the subbasin level by a weighted average. For climate, SWAT calculates a centroid for each subbasin and uses the station nearest to that centroid. Runoff is predicted separately for each HRU and routed at subbasin level to obtain total runoff figures (Neitsch et al, 2011). Surface runoff is estimated using a modified SCS curve number method, which estimates amount of runoff based on local landuse, soil type, and antecedent moisture condition. Watershed concentration time is estimated using Mannings formula for both overland and channel flows. Soil profiles are divided into multiple layers, which influence soil water processes like plant water uptake, later flow and percolation to lower layers as well as infiltration and evaporation. Potential evapotranspiration can be modelled with the PenmanMonteith, the PriestleyTaylor, or the Hargreaves method (Neitsch et al, 2011), depending on data availability.

In this study, surface runoff was estimated using the Natural Resources Conservation Service Curve Number (SCS-CN) method (USDA-SCS, 1972). Sediment loss for each HRU was calculated through the Modified Universal Soil Loss Equation (MUSLE), and routing in channels was estimated using stream power (Williams, 1969). The Hargreaves method (Hargreaves and Samani, 1985) was used to estimate potential evapotranspiration and the water balance in the watershed was simulated using Neitsches equation (Neitsch et al, 2011). Finally, sediment deposition in channels was calculated using fall velocity (Arnold et al, 2012). All equations and ensuing descriptions of elements can be found in SWAT theoretical documentation Version 2009 (Neitsch et al, 2011).

2.3 Model parametrization

A high-resolution ( $5 \mathrm{~m} \times 5 \mathrm{~m}$ ) digital elevation model (DEM) from the Advanced Land Observing Satellite Daichi (Alos of the Japan Aerospace Exploration 
Agency (JAXA)) was used to setup the SWAT model. Subbasin partitioning and stream networks were computed automatically through the ArcSWAT interface with the manual configuration of the outlet feature classes to include the Minchet catchment as a calibration feature at the top of the Gerda watershed (see Figure 1 for details). A drainage area of 100 ha was chosen as a threshold for delineation of the catchment as they approximately correspond to the Minchet sub-catchment size.

Data on agricultural practices were obtained from the Water and Land Resource Centre (WLRC, formerly the Soil Conservation Research Programme (SCRP)), and from the authors' fieldwork and interviews conducted in 2008, 2012 , and 2014. The land use data were adapted from a land use map with a field-scale resolution and nine land use categories, which was recorded in 2014 (WLRC, 2016). Tillage was implemented using heat units, and the results were cross-checked with the observed seasonal incidence and adapted as necessary based on planting and harvesting dates from field interviews (Ludi, 2004; Roth, 2010). In addition, the traditional Ethiopian ploughing tool called Maresha was added to the ArcSWAT management database. The Maresha was assigned a tillage depth of $20 \mathrm{~cm}$ and mixing efficiency of 0.3 (Temesgen et al, 2008; Dile and Srinivasan, 2014).

The physical and chemical parameterization of the soil maps was adapted from the WLRC soil report (Belay, 2014) and, where WLRC data were missing, from the doctoral dissertation of Zeleke (2000), from the SCRPs Soil Conservation Research Report 27 for the Minchet catchment (Kejela, 1995), and from Hurni (1985). The land use and soil data contained 19 soil and 12 land use classes (see Figure 2 for details) The model setup comprised 2,349 HRUs within 12 sub-basins. The model was created using a zero per cent threshold, meaning all HRUs were accounted for in modeling. Daily precipitation records combined with minimum and maximum temperature records for the Minchet watershed were used to run the model. Weather station data from Yechereka were added for the years 2013 and 2014. Solar radiation, potential evapotranspiration and wind speed were generated by the ArcSWAT weather generator. Storm-based sediment concentrations measured at the Minchet and the Yechereka outlets were used for model calibration and validation. Flow observations were available for the entire year, while sediment data were only available during rainfall events. The sediment concentration in the Gerda watershed is measured only during the rainy season, which is from June to October and assumed to be negligible during the remaining months. This is a realistic assumption given the extremely low sediment concentration during the dry season (Easton et al, 2010; Betrie et al, 2011).

\subsection{Model evaluation}

The ArcSWAT model was run on a daily time step for a period of 31 years (1984 to 2014), including a warm-up period of two years. The model was calibrated using SUFI-2 in the SWAT-Cup (Version 5.1.6.2), using the objective function 
' $b R^{2}$, where the coefficient of determination $R^{2}$ is multiplied by the coefficient of the regression line between measured and simulated data (Abbaspour et al, 2015). Through this function discrepancies between magnitudes of the two signals as well as their dynamics are accounted for.

$$
b R^{2}=\left\{\begin{array}{l}
|b| R^{2} \text { if }|b|<1 \\
|b|^{-1} R^{2} \text { if }|b|>1
\end{array}\right.
$$

The threshold value of the objective function was set to 0.6 , which is the minimum applicable value according to Faramarzi et al (2013) and Schuol et al (2008). The measured data were divided into two periods for calibration and validation. The calibration and validation periods were selected based on the availability of data and based on equally distributed years with similar amplitudes and seasonal occurrences of rainfall and discharge. Due to a prolonged gap in the Minchet catchment discharge data from SCRP/WLRC after the year 2000, the calibration period was set from 1984 to 2000 (without 1999) and the validation period was set from 2010 to 2014 . Calibration was done for the Minchet catchment only. Subsequently, the model parameter ranges were transferred to the entire catchment, where discharge and sediment loads were validated with measured discharge and sediment load data from the outlet at Gerda.

In this study model, evaluation was first performed following the calibration technique by Abbaspour (2015) and Arnold et al (2012b) for P-factor and $\mathrm{R}$-factor before considering model performance ratings suggested by Moriasi et al (2007) for commonly applied statistical parameters: (i) the Nash-Sutcliffe efficiency (NSE), (ii) the ratio of the root-mean-square error to the standard deviation of measured data (RSR), and (iii) the percent bias (PBIAS). When using SUFI-2, the first evaluation aims at reaching reasonable results for $\mathrm{P}$ factor and R-factor. The P-factor is the percentage of observed data enveloped by the modelling results - called 95 per cent prediction uncertainty, or 95PPU -while the R-factor is the relative thickness of the 95PPU envelope. Suggested values for the $\mathrm{P}$-factor are $>0.70$ for discharge and an $\mathrm{R}$-factor around 1 (Abbaspour et al, 2015); if the measured data are of high quality then the Pfactor should be $>0.80$ and R-factor $<1$. According to Schuol et al (2008) for less stringent model quality requirements the P-factor can be $>0.60$ and R-factor $<1.3$.

The NSE ranges from $-\infty$ (negative infinity) to 1 , with 1 representing perfect concordance of modelled to observed data, 0 representing balanced accuracy, and observations below zero representing unacceptable performance Nash and Sutcliffe (1970).

$$
N S E=1--\frac{\sum_{i=1}^{n}\left(Q_{o b s}^{i}--Q_{\text {sim }}^{i}\right)^{2}}{\sum_{i=1}^{n}\left(Q_{o b s}^{i}--Q_{o b s}^{\text {mean }}\right)^{2}}
$$

Where $Q_{\text {obs }}^{i}$ and $Q_{\text {sim }}^{i}$ are the observed and simulated data at the $i^{\text {th }}$ time step respectively. $Q_{o b s}^{\text {mean }}$ is the average of the observed data and $\mathrm{n}$ is the total number of observations. 


$$
R S R=\frac{R M S E}{S T D E V_{\text {obs }}}=\frac{\sqrt{\sum_{i=1}^{n}\left(Q_{o b s}^{i}--Q_{\text {sim }}^{i}\right)^{2}}}{\sqrt{\sum_{i=1}^{n}\left(Q_{o b s}^{i}--Q_{\text {mean }}\right)^{2}}}
$$

The RSR is a standardized RMSE, which is calculated from the ratio of the RMSE and the standard deviation of measured data $\left(S T D E V_{o b s}\right)$. RSR incorporates the benefits of error index statistics and includes a scaling factor. RSR varies from the optimal value of 0 , which indicates zero RMSE or residual variation, which indicates perfect model simulation to a large positive value Moriasi et al (2007).

$$
P B I A S=\frac{\sum_{i=1}^{n}\left(Q_{o b s}^{i}--Q_{s i m}^{i}\right) * 100}{\sum_{i=1}^{n}\left(Q_{o b s}^{i}\right)}
$$

The PBIAS measures the average tendency of the simulated values to be larger or smaller than their observed counterparts. The optimal value of PBIAS is zero. A positive PBIAS value indicates the model is underpredicting measured values, whereas negative values indicate overprediction of measured values.

Moriasi et al (2007) defined model performance ratings for evaluation divided into unsatisfactory, satisfactory, good, and very good. For this study we applied these recommendations strictly for hydrology and sediment loss.

A model can be considered as calibrated if there are significant NS, RSR or PBIAS between the best simulation and the measured data for a calibration and a test (validation) data set while P-factor and R-factor are within defined ranges (Abbaspour et al, 2007a; Moriasi et al, 2007).

\section{Results and discussion}

\subsection{Sensitivity analysis and calibration}

A sensitivity analysis for seventeen streamflow and sediment load variables was carried out in a first step of calibration. These variables were gathered from several articles (Abbaspour et al, 2007a; Talebizadeh et al, 2010; Arnold et al, 2012; Abbaspour et al, 2015) and separated into two categories. The first category contained variables that only affect hydrology and the second category contained variables that affect both hydrology and sediment load. First the hydrology was calibrated to a satisfactory level before integrating sediment loss variables. In a second step, sediment loss was then calibrated together with the hydrology but the hydrological parameters were kept within the previously calibrated ranges. Both calibrations were performed in SWAT-Cup using SUFI-2 and were run with 500 iterations each. Final results of calibrated parameter ranges are presented in Table 1. Parameters were ranked according to their respective sensitivities. The curve number (CN2) followed by the groundwater revap coefficient (GW_REVAP) and the deep aquifer percolation fraction (SOL_AWC) were most sensitive for the hydrology. Measured and simulated 
results were correlated at the outlet of the Minchet catchment (Subbasin 1), while validation was carried out at the outlet of the Minchet catchment and at the outlet of the entire catchment at Gerda (Subbasin 11). The calibrated model uncertainty assessment was determined through P-factor and R-factor quantification. The model was able to explain $88 \%$ of the observations within a very narrow $95 \mathrm{PPU}$ band of 0.57 .

Statistical performance for the calibration of hydrology in the Minchet catchment quantified by RSR (0.29), NSE (0.92) and PBIAS (-14.9) were very good, although PBIAS indicated a slight overprediction. Measured and simulated hydrographs were plotted for visual comparison including calibration and validation periods for Minchet and Gerda and visual distribution of the 95PPU band (see Figures 3 and 7 for details).

The hydrograph of the individual years (Figures 5) shows that streamflow is adequately represented for each year and that, except for some minimal over-predictions, amplitudes and seasonal incidences were very well reflected.

Sediment loss calibration performed fairly well with satisfactory results. The model could explain $45 \%$ of the observations within a reasonable 95PPU band (1.04), while statistical parameters yielded satisfactory results for RSR (0.65), NSE (0.57) and good results for PBIAS (10.1). PBIAS indicated a minor under-prediction of sediment loss modeling. The visual interpretation of sediment calibration in the Minchet catchment showed a satisfactory overall agreement. The model generally slightly under-predicted the sediment load and generated some minor unexplained peaks (see Figures 6 and 8 for details).

The calibrated parameter ranges for hydrology and sediment loss were later used for the validation of the model for (1) the Minchet catchment and for (2) the uncalibrated Gerda catchment at the outlet downstream (see Figure 1 for details).

\subsection{Validation of streamflow and sediment load}

3.3 Hydrologic and sediment load responses during validation period

The calibrated parameter ranges were applied to the validation period from 2010 to 2014 in SWAT-Cup. Hydrology validation for the Minchet catchment performed very satisfactorily with $73 \%$ of all observation explained by the model with a very narrow 95PPU band (0.45). Statistical parameters were very good considering Moriasi's performance ratings (2007). RSR (0.32), NSE (0.90), and PBIAS (-13.7) were better than for calibration. This result could be in relation with differing general conditions between the calibration and the validation period, which could lead to differences in performance rating results for the respective periods as proposed by Zhang et al (2008).

The sediment validation for the period from 2010 to 2014 for the Minchet catchment bracketed $42 \%$ of all observations with a 95PPU band of 1.09 . Statistical parameters were good with RSR (0.59), NSE (0.65), and PBIAS (19.5). These results were slightly less efficient than the ones achieved bySetegn 
et al (2010) with very good RSR (0.29), and NSE (0.79) but with a less accurate PBIAS (0.30).

The hydrograph of this validation period (see Figure 3 ) shows a close agreement for streamflow and for sediment loss. The main discrepancies arise for the peaks during the main rainy season, and for the duration and the extent of the dry season. Increased uncertainty, shown through larger 95PPU bands, follow the same logic and mainly arise at peak and low-flow levels.

3.4 Hydrologic and sediment loss validation for parameter transferred catchment

Validation was also carried out for the entire Gerda catchment as to find out if a model parameter transfer from a catchment within a larger catchment is applicable and can be successfully achieved. For this, the calibrated parameter ranges from the Minchet catchment calibration were used to validate the model in the entire Gerda catchment, which is forty-six times larger. The hydrology validation yielded very good results in the performance rating proposed by Moriasi et al (2007). With an R-factor showing that $68 \%$ of all observations could be explained with the model with a 95PPU band of 0.71 and very good RSR (0.45), NSE (0.79) the model validation was all in all satisfactory. Only PBIAS (-42.9) showed an unsatisfactory result, which can be explained with the fact that 2013 and 2014 were two extremes of climatic years. 2013 had very high rainfall events with the highest annual rainfall in the Minchet catchment recorded while 2014 was a very low-rainfall year. Knowing these facts, the validation of the model in the Gerda catchment through model parameter transfer only, yielded very good results.

\subsection{Catchment water balance and general results}

Besides comparing the statistical parameters, which showed a close agreement for streamflow and sediment loss, we chose to monitor the water balance for the catchment. The movement of water through the continuum of the soil, the vegetation and the atmosphere is important to understand annual variability of water balance components (Neitsch et al, 2011) and is important to understand if a model is realistically moving the water components in a catchment. Water balance distribution represented as components averaged over the entire simulation period divided into calibration and validation is shown in Table 5. The table includes precipitation (PCP), initial soil water content (SW), evapotranspiration (ET), surface runoff (SURQ), lateral flow (LATQ), groundwater (GWQ), percolation (PERC), water yield (WYLD) and sediment yield (SEDYLD). Simulated annual average baseflow to total discharge ratio was 0.77 while the annual average baseflow to total flow ratio obtained through digital filter methods from observed discharge averaged to $0.71(+8.4$ $\%)$. Streamflow to preciptation ratio for from model output obtained a ratio 
of 0.56 while the comparison of measured streamflow to precipitation ratio showed $0.6(-6.6 \%)$.

We compared the modeled sediment yield results for Minchet catchment to WLRC compiled sediment yield results and to other studies (Bosshardt, 1997; Setegn et al, 2010; Guzman et al, 2013; Lemann et al, 2016), which show reported mean annual sediment yields from $19.3 \mathrm{ha}^{-1} \mathrm{y}^{-1}$ to $29.5 \mathrm{ha}^{-1} \mathrm{y}^{-1}$ and resulting in an overall mean annual sediment yield of $26.12 \mathrm{ha}^{-1} \mathrm{y}^{-1}$ for the period of 1984 to 1993. The long term mean annual measured sediment yield from the WLRC grab samples for our study from 1984 to 2014 are $20.65 \mathrm{ha}^{-1} \mathrm{y}^{-1}$ while the SWAT modeled annual mean was $18.8 \mathrm{ha}^{-1} \mathrm{y}^{-1}(-8.95 \%)$.

We then compared the modeled sediment yield results for the entire Gerda catchment to WLRC measured data. The SWAT modeled annual sediment yield was $27.07 \mathrm{ha}^{-1} \mathrm{y}^{-1}$ while the measured amount resulted in a mean annual sediment yield of $30.35 \mathrm{ha}^{-1} \mathrm{y}^{-1}(-8.7 \%)$.

\section{Conclusions}

The overall aim of this study was to evaluate the SWAT model performance (1) in the Minchet catchment and (2) to evaluate a possible model parameter transfer from a subcatchment to a substantially larger watershed through validation alone. The results showed that the SWAT model could, with a high agreement, catch the amount and the variations for both streamflow and sediment loss in the Minchet subcatchment. Monthly and annual mean discharge and sediment loss were easily reproduced, while the catchment water balance was highly accurate and realistic.

Overall, the results of the SUFI-2 calibration with $\mathrm{b} R^{2}$ objective function in the Minchet sub-catchment and the Gerda catchment produced reasonable outcomes for calibration and validation as well as for uncertainty analysis. The model parameter transfer from the calibrated subcatchment to the uncalibrated watershed resulted in reasonable goodness of fit ratings for hydrology and just below the satisfactory threshold for sediment without any prior calibration.

The results showed that the SWAT model was able to capture streamflow amounts and streamflow variability for both catchments major deviations and optimized parameter ranges produced better results at the monitoring site of the calibrated watershed.

The applied SUFI-2 optimization scheme produced reasonable outcomes for calibration, uncertainty analysis, and validation of the SWAT model. This means that the model calibrated in the subwatershed could be used to model the entire watershed through model parameter transfer within a reasonable deviation of under $10 \%$ for both streamflow and sediment loss.

Acknowledgements This research was supported by the Centre for Development and Environment and the Institute of Geography, University of Bern, Switzerland. We are grateful to the Water and Land Resource Centre, Addis Abeba, Ethiopia, for providing data and support for field work. 


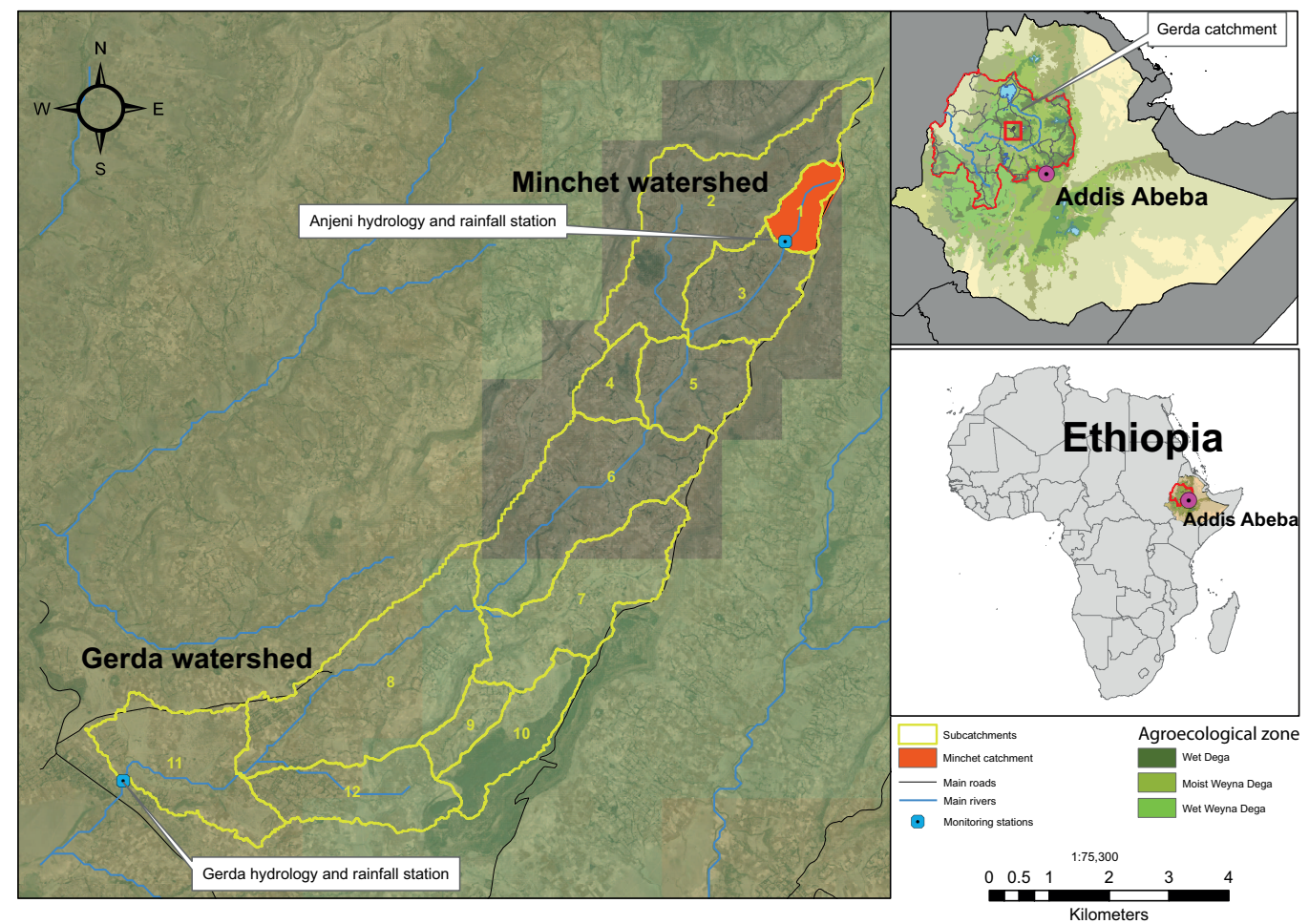

Fig. 1 Overview of Gerda watershed and location

\section{References}

Abbaspour KC, Vejdani M, Haghighat S, Yang J (2007a) SWAT-CUP Calibration and Uncertainty Programs for SWAT. In: The fourth International SWAT conference, Delft, Netherlands, pp 1596-1602

Abbaspour KC, Yang J, Maximov I, Siber R, Bogner K, Mieleitner J, Zobrist J, Srinivasan R (2007b) Modelling hydrology and water quality in the prealpine/alpine Thur watershed using SWAT. Journal of Hydrology 333(24):413-430, DOI 10.1016/j.jhydrol.2006.09.014

Abbaspour KC, Rouholahnejad E, Vaghefi S, Srinivasan R, Yang H, Kløve B (2015) A Continental-Scale Hydrology and Water Quality Model for Europe: Calibration and uncertainty of a high-resolution large-scale SWAT model. Journal of Hydrology DOI 10.1016/j.jhydrol.2015.03.027

Arnold JG, Moriasi DN, Gassman PW, Abbaspour KC, White MJ, Srinivasan R, Santhi C, Harmel RD, Van Griensven A, Van Liew MW, Kannan N, Jha MK (2012) SWAT: Model use, calibration and validation. Transactions of the ASABE 55(4):1491-1508

Belay G (2014) Gerda Watershed Soil Report. Tech. Rep. February, Water and Land Resource Centre (WLRC), Addis Abeba, Addis Abeba 

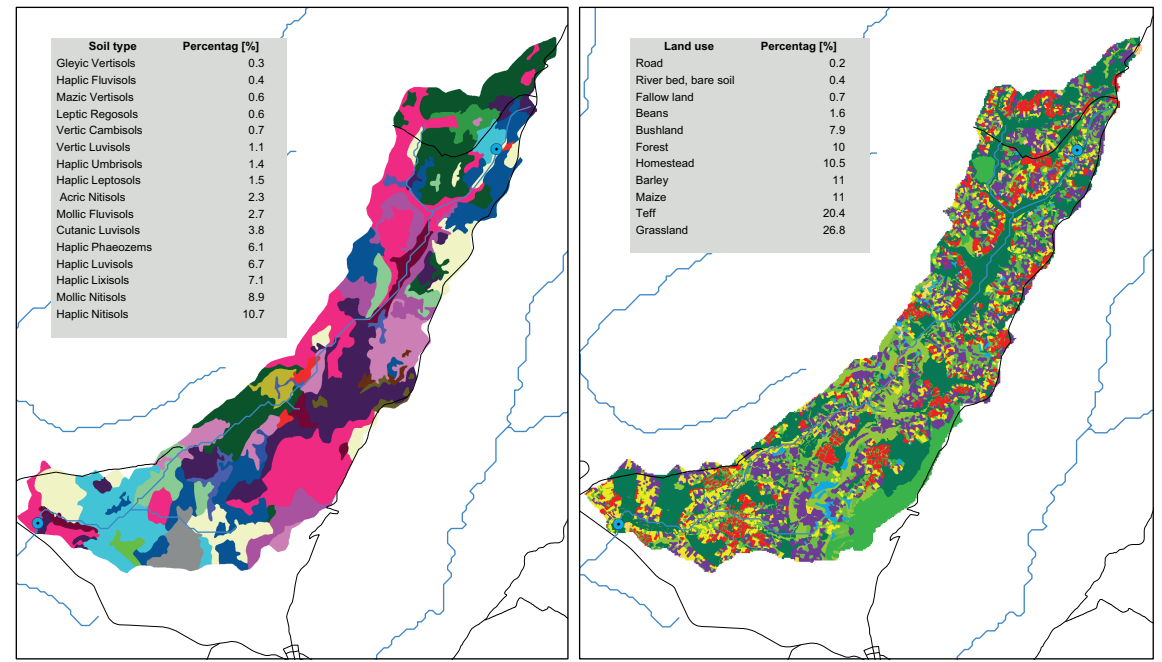

Soil types

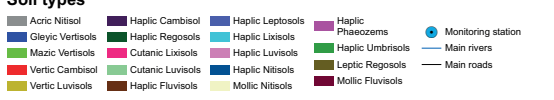

Land use types

Fig. 2 Soil map (a) and land use map (b) of Gerda watershed including details about area distribution
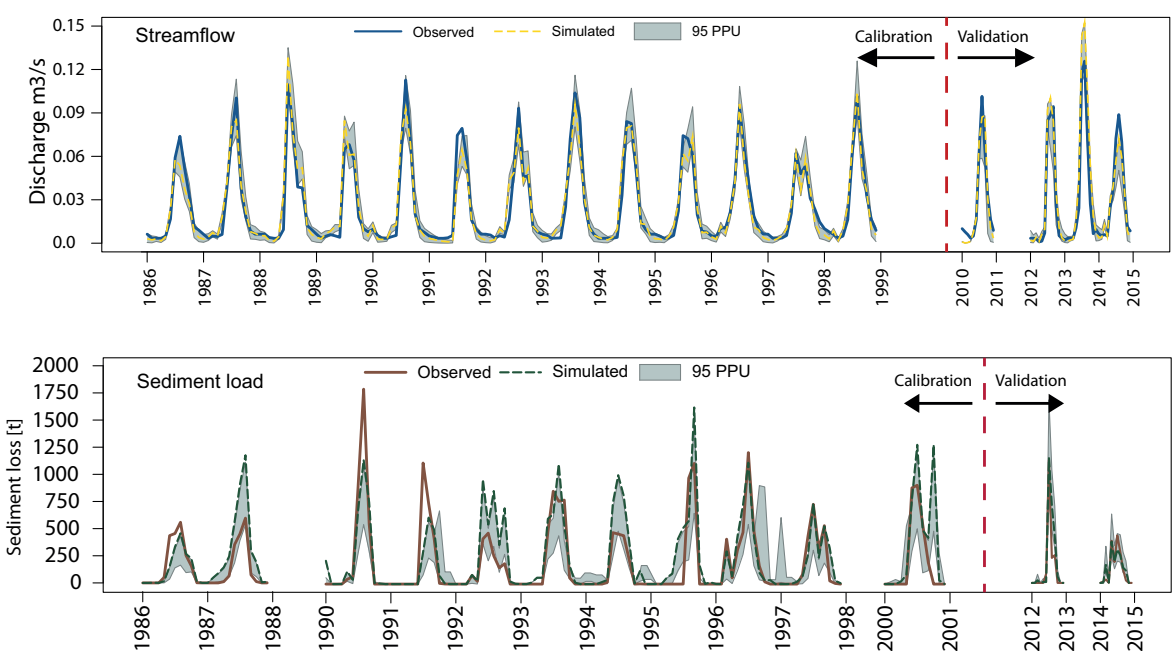

Fig. 3 Calibration and validation graphic in the Minchet catchment. On top the streamflow calibration and validation and at the bottom the same for sediment loss 

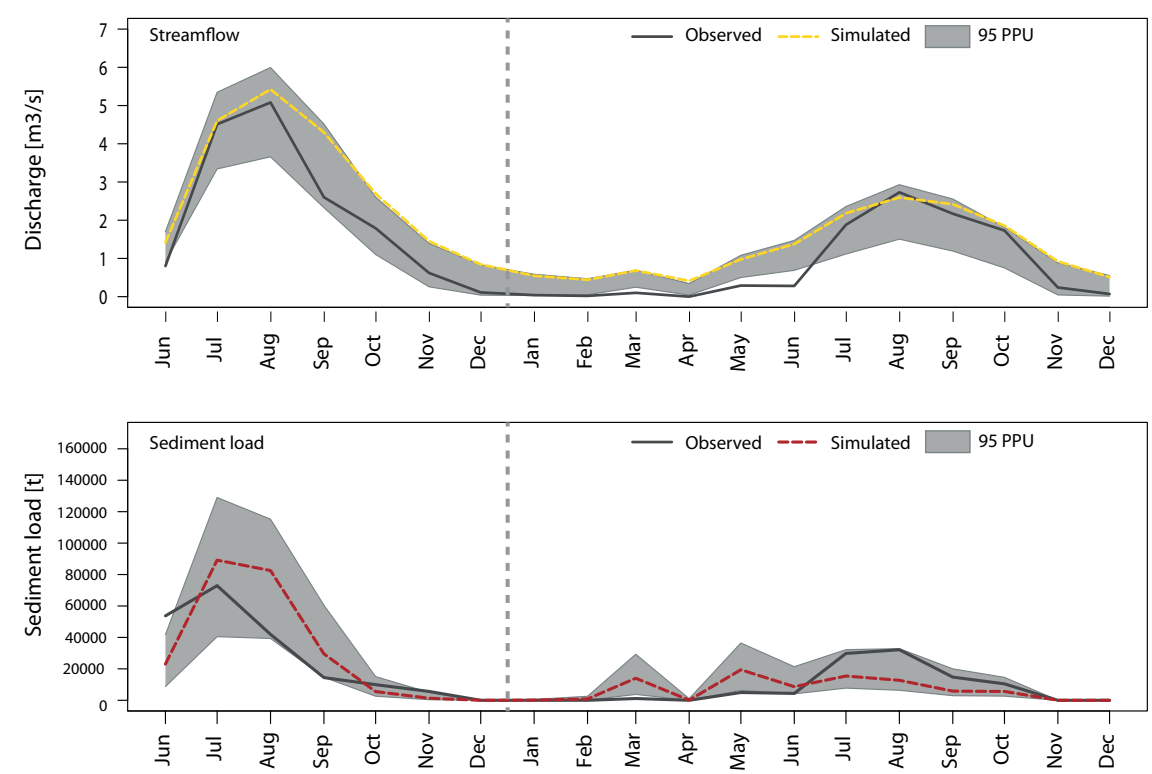

Fig. 4 Validation results for model parameter transfer to the Gerda catchment. On top the streamflow validation and at the bottom the sediment load validation

Betrie GD, Mohamed Ya, van Griensven A, Srinivasan R (2011) Sediment management modelling in the Blue Nile Basin using SWAT model. Hydrology and Earth System Sciences 15(3):807-818, DOI 10.5194/hess-15-8072011

Beven K (1993) Prophecy, reality and uncertainty in distributed hydrological modelling. Advances in Water Resources 16(1):41-51, DOI 10.1016/03091708(93)90028-E

Bingner R, Garbrecht J, Arnold J, Srinivasan R (1997) Effect of watershed subdivision on simulation runoff and fine sediment yield. Transactions of the Americal Society of Agricultural Engineers 40(5):1329-1335

Bosshardt U (1997) Catchment Discharge and Suspended Sediment Transport as Indicators of Physical Soil and Water Conservation in the Minchet Catchment, Anjeni Research Unit. Soil Conservation Research Programme, Bern, Switzerland

Chaubey I, Chiang L, Gitau MW, Mohamed S (2010) Effectiveness of best management practices in improving water quality in a pasture-dominated watershed. Journal of Soil and Water Conservation 65(6):424-437, DOI 10.2489/jswc.65.6.424

Dile YT, Srinivasan R (2014) Evaluation of CFSR climate data for hydrologic prediction in data-scarce watersheds: an application in the Blue Nile River Basin. JAWRA Journal of the American Water Resources Association 50(5):1226-1241, DOI 10.1111/jawr.12182

Douglas-Mankin KR, Daggupati P, Sheshukov aY, Barnes PL (2013) Paying for sediment: Field-scale conservation practice targeting, funding, and as- 

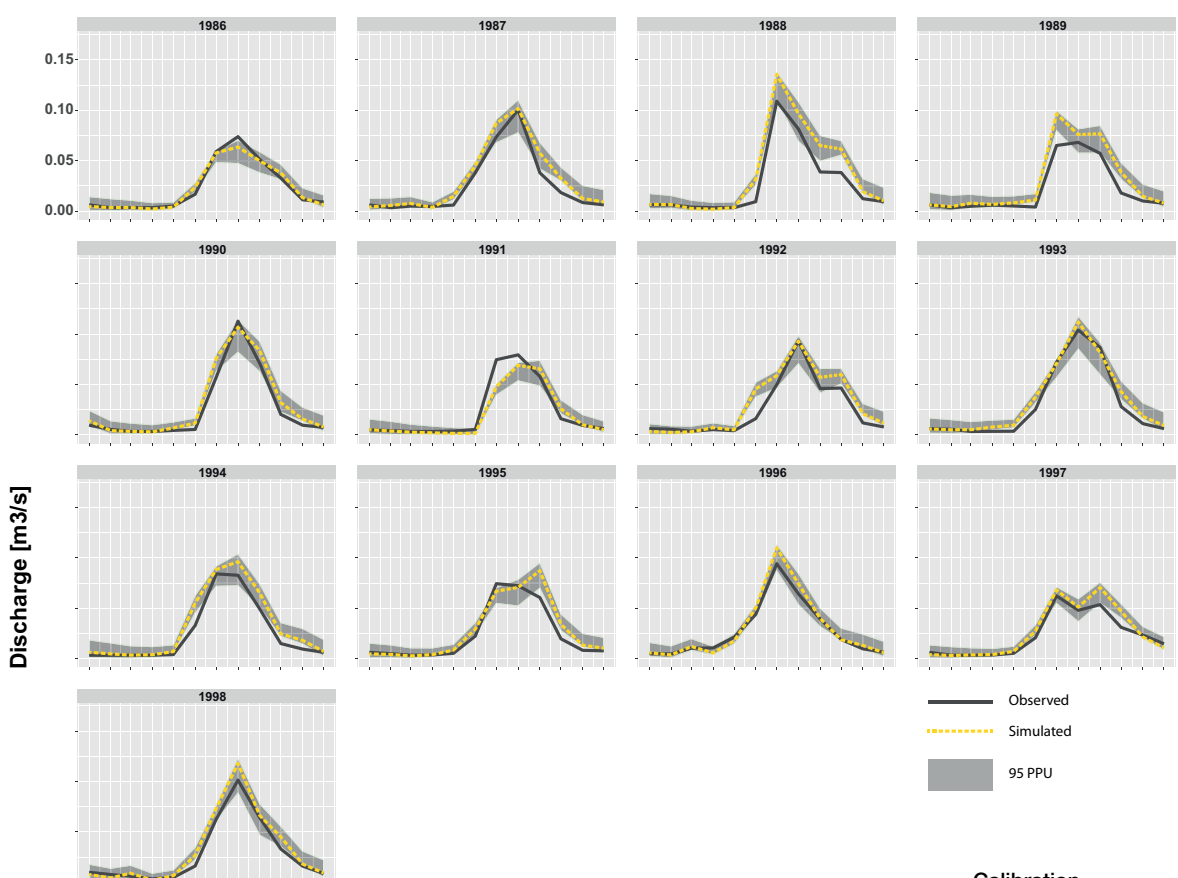

Calibration

Validation
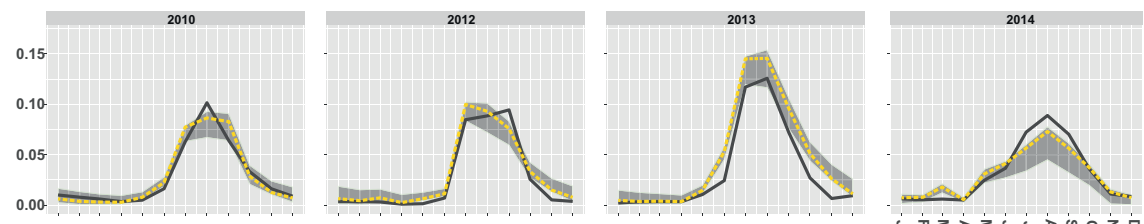

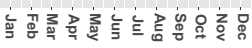

Fig. 5 Year by year calibration and validation results for streamflow in the Minchet catchment.

sessment using the Soil and Water Assessment Tool. Journal of Soil and Water Conservation 68(1):41-51, DOI 10.2489/jswc.68.1.41

Easton ZM, Fuka DR, White ED, Collick AS, Biruk Ashagre B, McCartney M, Awulachew SB, Ahmed AA, Steenhuis TS (2010) A multi basin SWAT model analysis of runoff and sedimentation in the Blue Nile, Ethiopia. Hydrology and Earth System Sciences 14(10):1827-1841, DOI 10.5194/hess14-1827-2010, URL http://www.hydrol-earth-syst-sci.net/14/1827/2010/

Faramarzi M, Abbaspour KC, Ashraf Vaghefi S, Farzaneh MR, Zehnder AJB, Srinivasan R, Yang H (2013) Modeling impacts of climate change on freshwater availability in Africa. Journal of Hydrology 480:85-101, DOI 10.1016/j.jhydrol.2012.12.016

Guzman CD, Tilahun SA, Zegeye AD, Steenhuis TS (2013) Suspended sediment concentrationdischarge relationships in the (sub-) humid Ethiopian 


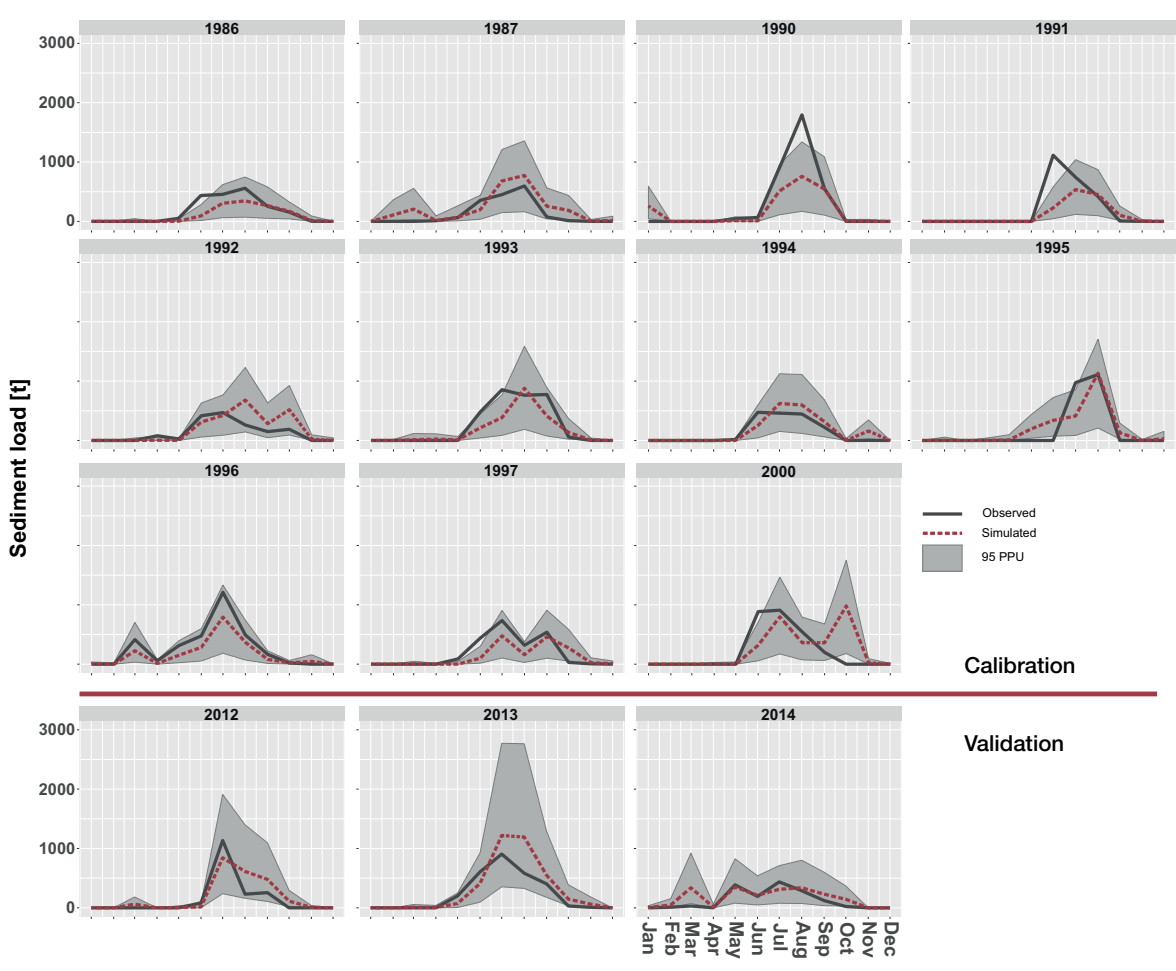

Fig. 6 Year by year calibration and validation results for sediment load in the Minchet catchment.

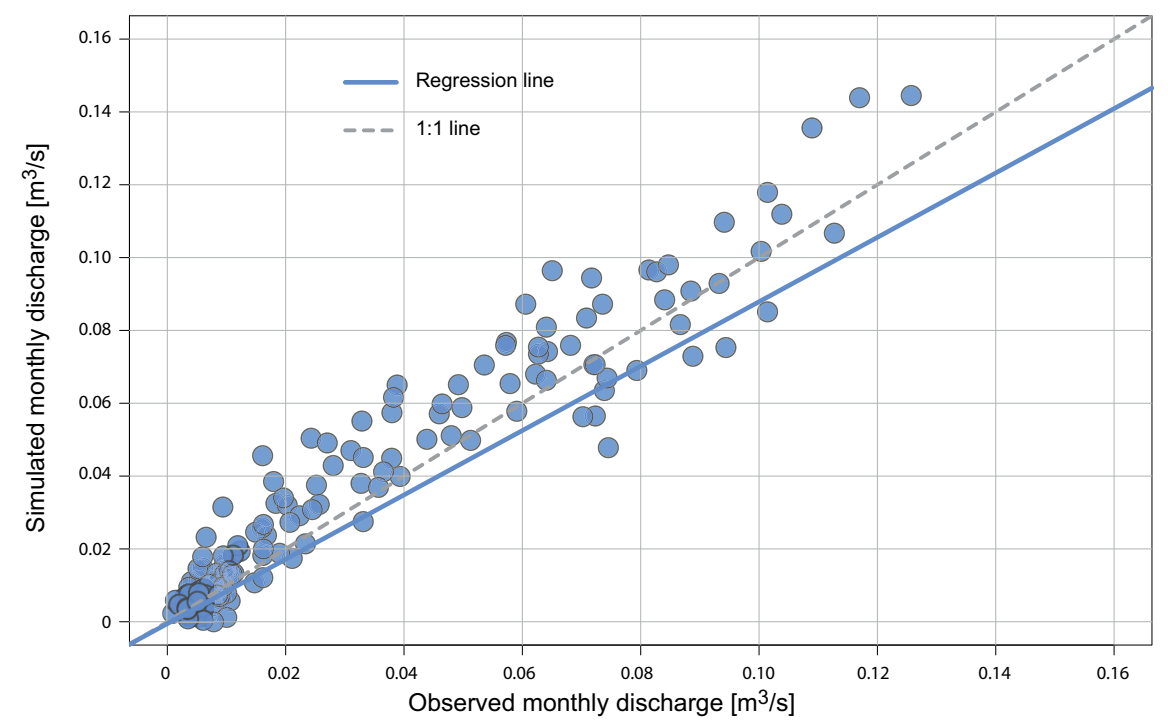

Fig. 7 Observed streamflow vs simulated streamflow dot plot for calibration 


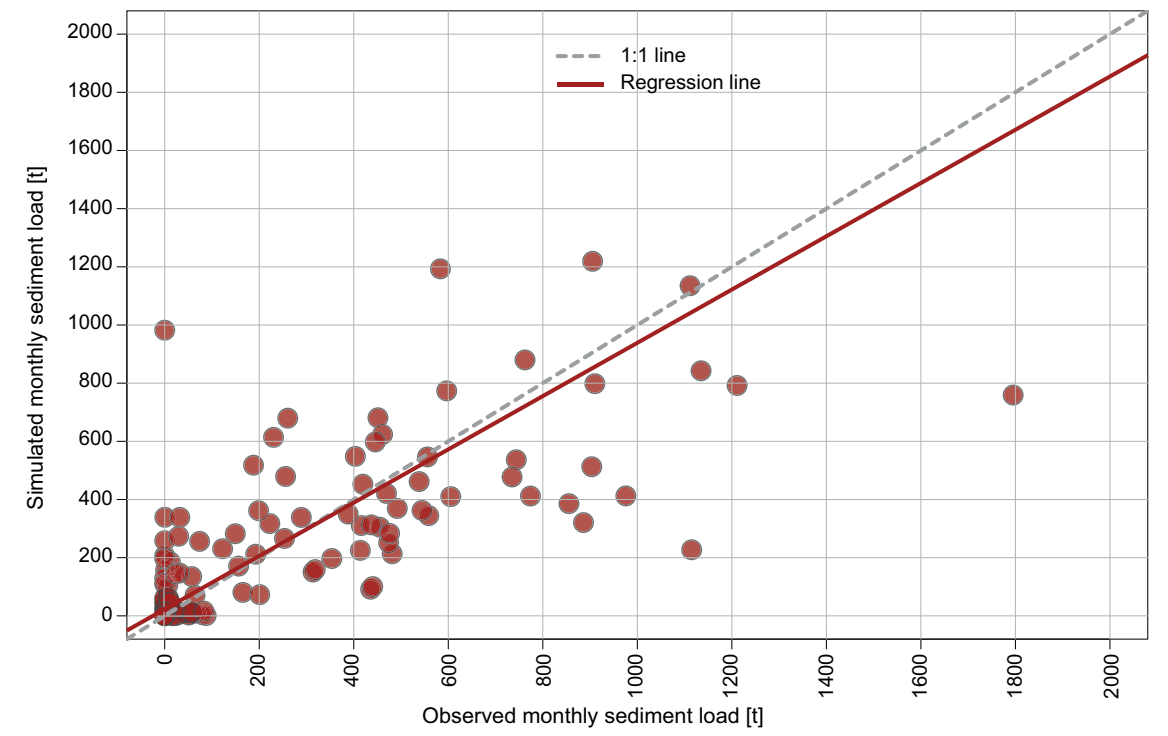

Fig. 8 Observed sediment vs simulated sediment dot plot for calibration

highlands. Hydrology and Earth System Sciences 17(3):1067-1077, DOI 10.5194/hess-17-1067-2013

Haddeland I (2002) Influence of spatial resolution on simulated streamflow in a macroscale hydrologic model. Water Resources Research 38(7):1-10, DOI 10.1029/2001WR000854

Hargreaves GH, Samani Za (1985) Reference crop evapotranspiration from temperature. Applied Engineering in Agriculture 1(2):96-99, DOI $10.13031 / 2013.26773$

He Y, Bárdossy A, Zehe E (2011) A review of regionalisation for continuous streamflow simulation. Hydrology and Earth System Sciences 15(11):35393553, DOI 10.5194/hess-15-3539-2011

Hurni H (1985) Erosion - productivity - conservation systems in Ethiopia. In: Pla Sentis I (ed) Pla Sentis, 1. (Edt.), Maracay, Venezuela, vol 674, pp 654-674

Kejela K (1995) The soils of the Anjeni Area - Gojam Research Unit, Ethiopia, research $\mathrm{r}$ edn. University of Bern, Switzerland, Bern, Switzerland

Kokkonen TS, Jakeman AJ, Young PC, Koivusalo HJ (2003) Predicting daily flows in ungauged catchments: Model regionalization from catchment descriptors at the Coweeta Hydrologic Laboratory, North Carolina. Hydrological Processes 17(11):2219-2238, DOI 10.1002/hyp.1329

Kumar R, Samaniego L, Attinger S (2013) Implications of distributed hydrologic model parameterization on water fluxes at multiple scales and locations. Water Resources Research 49(1):360-379, DOI 
Table 1 Streamflow and sediment load parameter ranges for calibration

\begin{tabular}{|c|c|c|c|c|}
\hline Variable & $\begin{array}{l}\text { Parameter } \\
\text { name }\end{array}$ & Definition & $\begin{array}{l}\text { Fitted parameter } \\
\text { range }\end{array}$ & $\begin{array}{l}\text { Sensitivity } \\
\text { ranking }\end{array}$ \\
\hline \multirow[t]{9}{*}{ Discharge } & a__CN2.mgt* & Curve number & number & 1 \\
\hline & v__GW_REVAP.gw & Groundwater "revap" coefficient & 0.02 to 0.2 & 2 \\
\hline & v__RCHRG_DP.gw & Deep aquifer percolation fraction & 0 to 1 & 3 \\
\hline & v__SOL_AWC(1).sol & Available water capacity of the soil layer & 0.85 to 1 & 4 \\
\hline & v_-GW_DELAY.gw & Groundwater delay (days) & 0 to 500 & 5 \\
\hline & v__ESCO.hru & Soil evaporation compensation factor & 0.33 to 0.49 & 6 \\
\hline & v__SURLAG.bsn & Surface runoff lag time & 0.05 to 24 & 7 \\
\hline & v__REVAPMN.gs & $\begin{array}{l}\text { Threshold depth of water in the shallow aquifer } \\
\text { for "revap" to occur ( } \mathrm{mm})\end{array}$ & number & 8 \\
\hline & v_-GWQMN.gw** & $\begin{array}{l}\text { Treshold depth of water in the shallow aquifer } \\
\text { required for return flow to occur }\end{array}$ & number & 9 \\
\hline \multirow[t]{9}{*}{ Sediment } & a__SLSUBBSN.hru & Average slope length & 0 to 6 & 25 to 37 \\
\hline & a__HRU_SLP.hru & Average slope steepness & -0.2 to 0.3 & -0.015 to -0.009 \\
\hline & a_-USLE_K(1).sol & USLE equation soil erodibility $(\mathrm{K})$ factor & -0.34 to 0.2 & -0.16 to -0.14 \\
\hline & v__CH_COV1.rte & Channel erodibility factor & -0.05 to 0.6 & -0.035 to 0.015 \\
\hline & v__SPEXP.bsn & $\begin{array}{l}\text { Exponent parameter for calculating sediment } \\
\text { reentrained in channel sediment routing }\end{array}$ & 1 to 1.5 & 1.24 to 1.35 \\
\hline & a_-USLE_C.plant.dat & $\begin{array}{l}\text { Min value of USLE C factor applicable } \\
\text { to the land cover/plant }\end{array}$ & 0.001 to 0.37 & 0.001 to 0.1 \\
\hline & a_-USLE_P.mgt & USLE equation support practice & -1.5 to -0.5 & -0.5 to 0 \\
\hline & v__PRF_BSN.bsn & $\begin{array}{l}\text { Peak rate adjustment factor for sediment } \\
\text { routing in the main channel }\end{array}$ & 0 to 2 & 0.5 to 1 \\
\hline & v_-SPCON.bsn & $\begin{array}{l}\text { Maximum amount of sediment that can be } \\
\text { reentrained during channel sediment routing }\end{array}$ & 0.0001 to 0.01 & 0.004 to 0.01 \\
\hline
\end{tabular}

$\mathrm{a}_{--}$means a given value is added to the existing parameter value;

$\mathrm{v}_{--}$means the existing parameter value is to be replaced by a given value

10.1029/2012WR012195

Lemann T, Zeleke G, Amsler C, Giovanoli L, Suter H, Roth V (2016) Modelling the effect of soil and water conservation on discharge and sediment yield in the upper Blue Nile basin, Ethiopia. Applied Geography 73:89-101, DOI 10.1016/j.apgeog.2016.06.008

Liang X, Guo J, Leung LR (2004) Assessment of the effects of spatial resolutions on daily water flux simulations. In: Journal of Hydrology, vol 298, pp 287-310, DOI 10.1016/j.jhydrol.2003.07.007

Ludi E (2004) Economic analysis of soil conservation. Phd thesis, University of Bern, Switzerland

McIntyre N (2004) Analysis of uncertainty in river water quality modelling. PhD diss London, England: University of London, p 224, URL http://www3.imperial.ac.uk/pls/portallive/docs/1/7253966.PDF 
Table 2 Calibration results for discharge and sediment loss modeling. Gerda catchment was validated only. Bold characters indicate above satisfactory threshold.

\begin{tabular}{lcc|cc}
\hline & \multicolumn{2}{c}{ CALIBRATION } & \multicolumn{2}{c}{ VALIDATION } \\
\hline $\begin{array}{l}\text { Performance } \\
\text { Rating }\end{array}$ & Minchet & Gerda & Minchet & Gerda \\
\hline \multicolumn{5}{c}{ Discharge } \\
\hline $\begin{array}{l}\text { P-factor } \\
R \text {-factor }\end{array}$ & $\mathbf{0 . 8 8}$ & - & $\mathbf{0 . 7 3}$ & 0.68 \\
RSR & $\mathbf{0 . 5 7}$ & - & $\mathbf{0 . 4 5}$ & $\mathbf{0 . 7 1}$ \\
NSE & $\mathbf{0 . 2 9}$ & - & $\mathbf{0 . 3 2}$ & $\mathbf{0 . 4 5}$ \\
PBIAS & $\mathbf{0 . 9 2}$ & - & $\mathbf{0 . 9 0}$ & $\mathbf{0 . 7 9}$ \\
\hline & $\mathbf{- 1 4 . 9}$ & - & $\mathbf{- 1 3 . 7}$ & -42.3 \\
\hline$P$-factor & $\mathbf{0 . 4 5}$ & - & $\mathbf{0 . 4 7}$ & 0.58 \\
$R$-factor & $\mathbf{1 . 0 4}$ & - & $\mathbf{1 . 0 9}$ & 1.28 \\
\hline RSR & $\mathbf{0 . 6 5}$ & - & $\mathbf{0 . 5 9}$ & 0.73 \\
NSE & $\mathbf{0 . 5 7}$ & - & $\mathbf{0 . 6 5}$ & 0.47 \\
PBIAS & $\mathbf{1 0 . 1}$ & - & $\mathbf{- 1 9 . 5}$ & $\mathbf{- 6 . 0}$ \\
\hline
\end{tabular}

Table 3 Description of study sites and main characteristics SCRP (2000)

\begin{tabular}{lcc}
\hline & Minchet & Gerda \\
\hline Year of construction & 1983 & 2012 \\
Location & $10.678^{\circ} \mathrm{N}$ & $10.597^{\circ} \mathrm{N}$ \\
& $37.530^{\circ} \mathrm{E}$ & $37.420^{\circ} \mathrm{E}$ \\
Size & $113.4 \mathrm{ha}$ & 4860.4 ha \\
Altitudinal range & $2406-2506 \mathrm{masl}$ & $1980-2506$ masl \\
Mean annual temperature & $16^{\circ} \mathrm{C}$ & - \\
Mean annual rainfall & $1690 \mathrm{~mm}$ & - \\
Mean annual discharge & $610-867 \mathrm{~mm}$ & - \\
Mean annual sediment loss & $25.2 \mathrm{t} / \mathrm{ha}$ & - \\
Farming system & Rainfed, smallholder, ox-plough farming \\
\hline
\end{tabular}

Mekonnen MA, Anders W, Dargahi B, Gebeyehu A (2009) Hydrological modelling of Ethiopian catchments using limited data. Hydrological Processes 23:3401-3408, DOI 10.1002/hyp.7470

Merz R, Blöschl G (2004) Regionalisation of catchment model parameters. Journal of Hydrology 287(1-4):95-123, DOI 10.1016/j.jhydrol.2003.09.028

Moriasi DN, Arnold JG, Liew MWV, Bingner RL, Harmel RD, Veith TL (2007) Model evaluation guidelines for systematic quantification of accuracy in watershed simulations. American Society of Agricultural and Biological Engineers 50(3):885-900

Nash JE, Sutcliffe JV (1970) River Flow Forecasting through Conceptual Models: Part 1. - A Discussion of Principles. Journal of Hydrology 10:282-290 
Table 4 Data sources and data resolution

\begin{tabular}{lcc}
\hline & Data sources and resolutions \\
\hline DEM & Alos World DEM \\
DEM resolution & $5 \times 5 m$ \\
Land use map & $*_{\text {field scale (WLRC) }}$ \\
Soil map & 1x1m (WLRC) \\
Climate data & continuous precipitation \\
& daily min and daily max temperature \\
Hydrology & continuous discharge \\
Soil loss data & storm event sediment loss \\
\hline & Data availability & \\
& Minchet & Gerda \\
\hline Precipitation data & $1984-2004$ & - \\
& $2010-2014$ & $2013-2014$ \\
Discharge data & $1984-1998,2000$ & \\
& $2010,2012-2014$ & \\
Soil loss data & $1986-1987$ & \\
& $1990-1997,2000$ &
\end{tabular}

2012,2014

\begin{tabular}{lcc}
\hline \multicolumn{3}{c}{ Calibration and validation subdivision } \\
\hline Calibration & $1986-1998 / 2000$ & - \\
Validation & $2010-2014$ & $2013-2014$ \\
\hline${ }^{*}$ field-scale: each field was attributed a land-use type
\end{tabular}

Table 5 Water balance ratios and sediment yield for average annual data

\begin{tabular}{llll}
\hline & Simulated & Measured & Difference \\
\hline Streamflow/Precipitation & 0.56 & 0.60 & $-6.6 \%$ \\
Baseflow/Total flow & 0.77 & 0.71 & $+8.4 \%$ \\
Sediment yield Minchet & 18.8 & 20.65 & $-8.95 \%$ \\
\hline
\end{tabular}

Ndomba PM, Mtalo FW, Killingtveit $\AA$ (2008) A guided SWAT model application on sediment yield modeling in Pangani river basin: Lessons learnt. Journal of Urban and Environmental Engineering 2:53-62, DOI 10.4090/juee.2008.v2n2.053062

Neitsch S, Arnold J, Kiniry J, Williams J (2011) Soil \& Water Assessment Tool Theoretical Documentation Version 2009. Tech. rep., Texas Water Resources Institute, College Station, Texas

Notter B, Hurni H, Wiesmann U, Abbaspour KC (2012) Modelling water provision as an ecosystem service in a large East African river basin. Hydrology and Earth System Sciences 16(1):69-86, DOI 10.5194/hess-16-69-2012

Parajka J, Merz R, Blöschl G (2005) A comparison of regionalisation methods for catchment model parameters. Hydrology and Earth System Sciences 
Discussions 2(2):509-542, DOI 10.5194/hessd-2-509-2005

Parajuli PB, Nelson NO, Frees LD, Mankin KR (2009) Comparison of AnnAGNPS and SWAT model simulation results in USDA-CEAP agricultural watersheds in south-central Kansas. Hydrological Processes 23(5):748-763, DOI 10.1002/hyp.7174

Roth V (2010) Abfluss- und Erosionsmodellierung im Hochland von Äthiopien. Master thesis, University of Bern, Switzerland

Samaniego L, Kumar R, Attinger S (2010) Multiscale parameter regionalization of a grid-based hydrologic model at the mesoscale. Water Resources Research 46(5), DOI 10.1029/2008WR007327

Santhi C, Arnold JG, Williams JR, Dugas WA, Srinivasan R, Hauck LM (2001) Validation of the SWAT model on a large river basin with point and nonpoint sources. Journal of the American Water Resources Association (JAWRA) 37(5):1169-1188

Schuol J, Abbaspour KC, Srinivasan R, Yang H (2008) Estimation of freshwater availability in the West African sub-continent using the SWAT hydrologic model. Journal of Hydrology 352(1-2):30-49, DOI 10.1016/j.jhydrol.2007.12.025

SCRP (2000) Area of Anjeni, Gojam, Ethiopia: Long-term Monitoring of the Agricultural Environment 1984-1994. Tech. rep., Centre for Development and Environment (CDE), Addis Abeba

Seo M, Yen H, Kim MK, Jeong J (2014) Transferability of SWAT Models between SWAT2009 and SWAT2012. Journal of Environment Quality 43(3):869, DOI 10.2134/jeq2013.11.0450

Setegn SG, Dargahi B, Srinivasan R, Melesse AM (2010) Modeling of sediment yield from Anjeni-gauged watershed, Ethiopia using SWAT model. Journal of the American Water Resources Association (JAWRA) 46(3):514-526

Sheshukov AY, Daggupati P, Douglas-Mankin KR, Lee MC (2011) High Spatial Resolution Soil Data for Watershed Modeling: 1. Development of a SSURGO-ArcSWAT Utility. Journal of Natural \& Environmental Sciences $2(2): 15-24$

Singh SK, Bárdossy A, Götzinger J, Sudheer KP (2012) Effect of spatial resolution on regionalization of hydrological model parameters. Hydrological Processes 26(23):3499-3509, DOI 10.1002/hyp.8424

Smith MB, Koren V, Zhang Z, Zhang Y, Reed SM, Cui Z, Moreda F, Cosgrove Ba, Mizukami N, Anderson Ea (2012) Results of the DMIP 2 Oklahoma experiments. Journal of Hydrology 418-419:17-48, DOI 10.1016/j.jhydrol.2011.08.056

Talebizadeh M, Morid S, Ayyoubzadeh SA, Ghasemzadeh M (2010) Uncertainty analysis in sediment load modeling using ANN and SWAT model. Water Resources Management 24:1747-1761, DOI 10.1007/s11269-009-9522-2

Temesgen M, Rockström J, Savenije HHG, Hoogmoed WB, Alemu D (2008) Determinants of tillage frequency among smallholder farmers in two semiarid areas in Ethiopia. Physics and Chemistry of the Earth 33:183-191, DOI $10.1016 / \mathrm{j}$.pce.2007.04.012 
USDA-SCS (1972) Design Hydrographs. In: National Engineering Handbook, USDA Soil Conservation Service, Washington D.C., Washington D.C., chap 1-22, p 824

Van Liew MW, Garbrecht J (2003) Hydrologic simulation of the Little Washita River experimental Watershed using SWAT. Journal of the American Water Resources Association 39(2):413-426, DOI 10.1111/j.17521688.2003.tb04395.x

Vandewiele G, Elias A (1995) Monthly water balance of ungauged catchments obtained by geographical regionalization. Journal of Hydrology 170(14):277-291, DOI 10.1016/0022-1694(95)02681-E

Williams JR (1969) Flood routing with variable travel time or variable storage coefficients. Transactions of the ASABE 12(1):100-103

WLRC (2016) Water and Land Resources Information System (WALRIS). URL http://walris.wlrc-eth.org/.

Yesuf HM, Melesse AM, Zeleke G, Alamirew T (2016) Streamflow prediction uncertainty analysis and verification of SWAT model in a tropical watershed. Environmental Earth Sciences 75(9):806, DOI 10.1007/s12665-016-5636-z

Zeleke G (2000) Landscape Dynamics and Soil Erosion Process Modeling in the North-Western Ethiopian Highlands. Phd thesis, University of Bern, Swizterland

Zhang X, Srinivasan R, Liew MV (2008) Multi-site calibration of the SWAT model for hydrologic modeling. Transactions of the ASABE 51(2007):2039 2049 